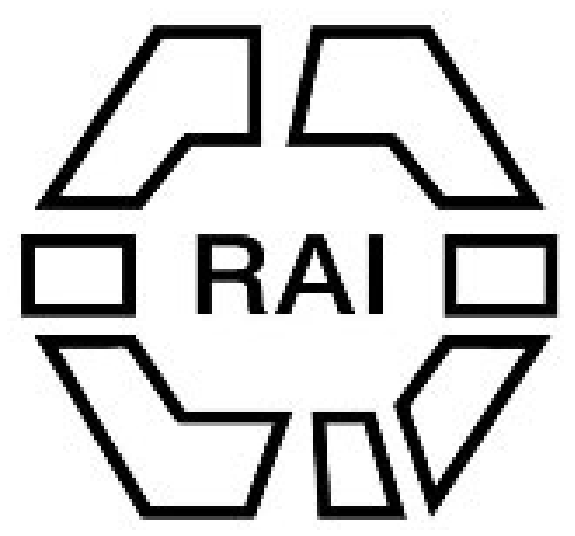

\title{
26. "Eoliths."
}

Author(s): Worthington G. Smith

Source: Man, Vol. 8 (1908), pp. 49-53

Published by: Royal Anthropological Institute of Great Britain and Ireland

Stable URL: http://www.jstor.org/stable/2840105

Accessed: 19/12/2014 01:23

Your use of the JSTOR archive indicates your acceptance of the Terms \& Conditions of Use, available at http://www.jstor.org/page/info/about/policies/terms.jsp

JSTOR is a not-for-profit service that helps scholars, researchers, and students discover, use, and build upon a wide range of content in a trusted digital archive. We use information technology and tools to increase productivity and facilitate new forms of scholarship. For more information about JSTOR, please contact support@jstor.org.

Royal Anthropological Institute of Great Britain and Ireland is collaborating with JSTOR to digitize, preserve and extend access to Man. 

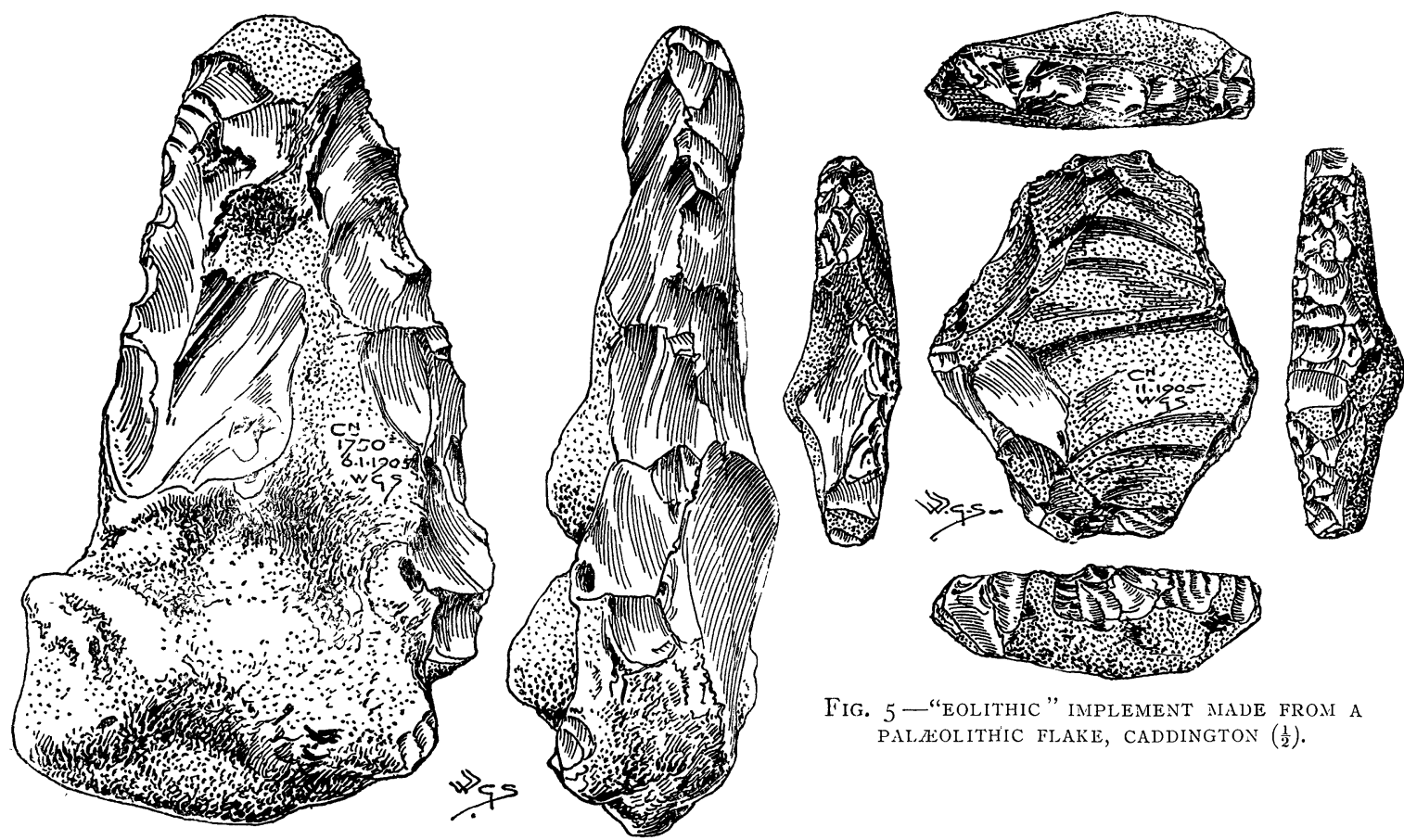

FIG. I.--CADDINGTON $\left(\frac{1}{2}\right)$

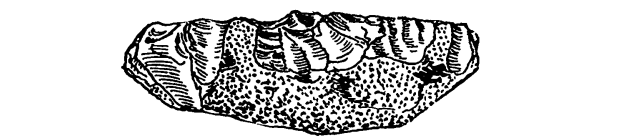

Fig. 5-"eolithic" implement ande from a

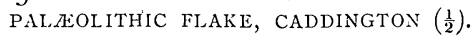

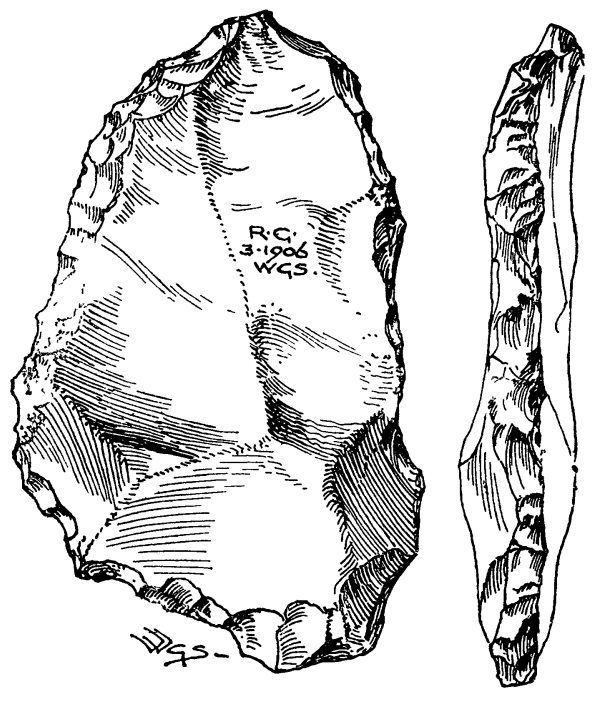

Fig. 6.-_" EOI.ITHIC" IMPLEMENT MADE FROM A PAL.æOLITHIC FLAKE, CADDINGTON $\left(\frac{1}{2}\right)$.

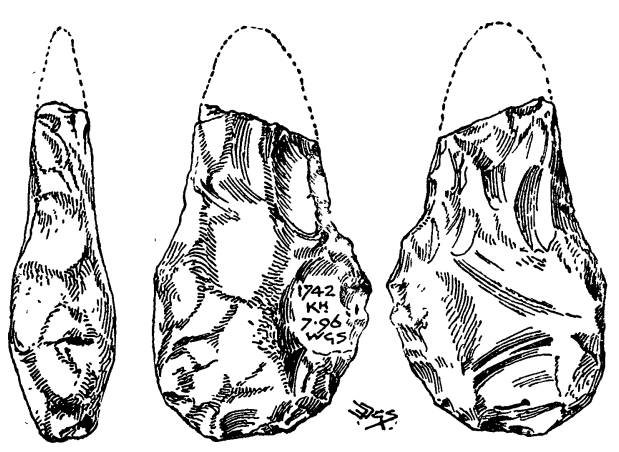

FIG. 3.--KENSWORTH $\left(\frac{1}{2}\right)$.

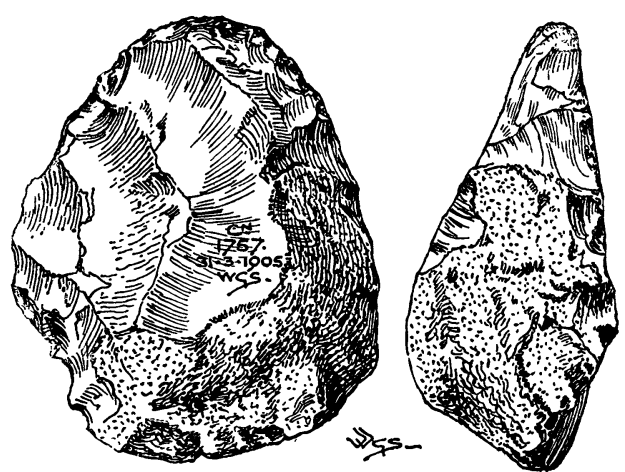

FIG. 2.--CADDINGTON ( $\left.\frac{1}{2}\right)$. 


\section{ORIGINAL ARTICLES.}

\section{England: Archæology. With Plate D.}

Smith.

"Eoliths." By Worthington G. Smith, F.L.S.

When Professor Prestwich published his paper on The Primitive Characters 26 of the Flint Implements of the Chalk Plateau of Kent, in the Journal of the Anthropological Institute, Vol. XXI., 1892, he appended a note at p. 247, in which he stated that "similar flint implements" had "also been found by Mr. Worthington Smith on " the hills near Dunstable, at heights of 596 and 760 feet, in positions away from " existing river valleys." In a letter in my possession Professor Prestwich "co-relates" the implements found on the Dunstable plateau with those found on the similar Kentish plateau. I also have a postcard in which Professor Prestwich requests me to make notes as to the high-level implements and the red clay-with-flints. At that time I was familiar with plateau implements.

As many years have now passed since my attention was first directed to these objects, it may possibly be of interest if I give the conclusions at which I have arrived regarding the North Herts and South Beds plateaux and their implements.

Early Searches on the Plateaux of the East of England.-Some years before $1871 \mathrm{my}$ late friend, Mr. Henry Prigg, the well-known geologist and antiquary of Bury St. Edmund's, whose name occurs so frequently in Evans' Stone Implements of Great Britain, called my attention to the palæolithic flint implements found by him on the high-level position at Barton Hill, one-and-a-half miles south of Mildenhall, Suffolk. Mr. Prigg sent me a drawing of a section taken through Barton Hill and Warren Hill, with the River Lark flowing between. In his accompanying letter he wrote: "The discovery of implements in the gravel of Barton Hill has not yet been published, " but it will be included in a paper I have for some time been preparing for pub" lication. The majority of implements found there are mere naturally fractured " stones, either used as they were, or adapted for use by a few additional flakes being " struck off them." In another letter Mr. Prigg wrote : "The stones from Barton "Hill are in many cases natural fractures, leaving a sharp side edge, and this has " been plainly worked off by rough use. In other cases the natural fracture is improved " upon to produce a handier implement. They are moderately abundant in the pits, " and now and then a better formed implement turns up."

Mr. Prigg here referred to the rude minor forms of palæolithic implements now called by some observers, "eolithic" implements, and he notes that "better formed implements" accompanied them. This is my experience on the North Herts and South Beds plateaux.

The paper Mr. Prigg was then preparing was one he afterwards forwarded, with drawings, to the Prehistoric Congress of Bologna in 1871, one year before the publication of Evans' Stone Implements. In this he referred to high-level tools as "plateau" implements. Mr. Prigg sent the paper to me for perusal with examples of the stones. I have not seen the Bologna report, but the paper was printed in English, in abstract form, without illustrations, under the name of "Notes upon some Discoveries " of Flint Implements in the Quaternary Deposits of the East of England," in the Journal of the Norwich Geological Society, March 1882. Mr. Prigg sent a copy of this paper to antiquaries and geologists.

At p. 163 of this paper Mr. Prigg says : "Other implement-bearing gravels are "found upon the top of some of the higher ground in the vicinity of the outfall of " these rivers"-Ouse and Lark-" which ground attains an elevation of from 90 to " 120 feet above the water level. These gravels, although of similar materials to

" those of the lower-level beds, now form part of no valley series and are of great " antiquity. It is probable that some of the more worn implements found in the 
" lower beds may have been derived from their waste." On p. 164 he says : "Similarly

" situated, but to the south of the valley of the Lark, a deposit of plateau gravel

" containing flint implements occur at Barton Hill, $1 \frac{1}{4}$ miles distant from, and fully

" 120 feet above, the River Lark." Mr. Prigg concludes by saying : "A vast antiquity

" must be assigned to the implements ; at the same time, the evidence thus far, fairly

" interpreted, will not allow us to assign to any of the beds containing them a greater

" age than those usually classed as quaternary or post-glacial."

The evidence of the Dunstable position points to conclusions identical with those formed by Mr. Prigg.

About the time of the writing of this paper, 1869, a high-level palæolithic implement was found by Messrs. Prestwich and Evans at Currie Farm, Halstead, at a height of 600 feet.

In $1882 \mathrm{Mr}$. Henry Prigg returned to this subject in a report on the drainage works at Bury St. Edmund's published in the Norwich and Bury Post. Writing as to the dates of his discoveries of palæolithic implements in 1865-7, he says : "Afterwards I " successfully sought them in the high-level deposits of Westley, Risby, Kentford, and "Rougham, stations occupying nearly the highest points in their respective localities, " and far removed from the influence of any river now draining the district." Further on he remarks: "That the high-level gravels were deposited by river action is abun" dantly proved by the presence in them of shells of snails, \&c., identical with those " now living in our streams, whilst their height, far above the greatest floods of the " present rivers, proves that the valleys must have been excavated since they were " deposited."

Mr. Prigg, who was hon. curator of the Bury Museum, sent this report to his geological and archæological friends.

The Dunstable Plateau. - The Dunstable plateau at its highest point is 800 feet O.D. and more than 200 feet above the nearest valley. Its lowest elevation is 530 feet O.D. and 75 feet above the nearest dry valley. The high-level positions are Dunstable Downs, Blow's Downs, Caddington, Kensworth, Round Green, Ramiridge End, and other places. The hills are of lower chalk, capped in an irregular manner by patches of the Reading beds, red clay-with-flints, boulder clay, in a washed and relaid condition, stones which at one time belonged to boulder clay and various blocks and pebbles derived from glacial and outlying tertiary beds. In many places brick-earth occurs, composed of washings from these deposits and it varies in colour according to the nature of the deposit from which it has been washed. In some places there is an upper capping of contorted drift.

In the brick-earth palæolithic implements of the latest date occur; this is shown by their small, refined, geometrically perfect and beautiful forms, they are unabraded and detached flakes are capable of replacement. These implements are only mentioned here because they prove that although they belong to the latest of palæolithic times, yet they are older than the excavation of the valleys. The valleys, if they existed, could only have been in an initial state.

The Contorted Drift.- This is of the greatest importance, it is post-glacial and newer than the boulder clay. Glacial deposits and boulder clays occur in the neighbourhood of Dunstable, and, as far as my experience goes, especially during the last twenty-two years, they are absolutely without a trace of human work. The contorted drift is deep red-brown in colour, highly tenacious and commonly, though not invariably, contorted. I have seen it at Kensworth 40 feet deep, with late, sharp, palæolithic ilakes at its base; it is commonly about 4 feet deep and sometimes it is weathered away to a few inches. It contains local stones belonging to the local deposits already mentioned. No stones in it have been brought direct from a long distance, all are derived from local and relaid deposits in the neighbourhood. Its chief interest is 
found in the fact that it contains palæolithic implements and flakes of various degrees of antiquity, side by side, and in the same mineral condition as those called by some observers "eolithic" implements. The implements and "eoliths" vary from sharp to greatly abraded and from deep brown to white. Any observation or criticism that applies to one applies with equal force to the other. The explanation is clear : the contorted drift picked up and fixed in its own tenacious substance all the stones that were resting upon the surface of the ground at the time of its deposition. These stones included all the local stones of the district, including older and newer palæoliths, and their ever-accompanying "eoliths."

"Eoliths."-What are "eoliths"? At the present day all kinds of oddities in flint are passed off as " eoliths": one author says the examples must be bulbless ; another describes well-formed bulbs. One says the secondary flaking is vertical, another that it is lateral. Sometimes a proof of authenticity is said to rest on the fact that the stones in question present no flaking at all, only rubbing. If museums are visited one sees ordinary palæoliths masquerading as "eoliths" and rubbing shoulders with minor well-known palæolithic forms, iron-stained neoliths, surface flints, and late Victorian oddities of all sorts. Professor Prestwich himself could not always distinguish palæoliths from "plateau" examples, for he says, in his Controverted Questions in Geology: "I do not wish to assert that all the plateau implements are of so distinct " a pattern that they can always be distinguished from the valley implements" (!) ; and, "Besides the implements of different patterns, there is a large, probably the larger, " number, which, though not the result of chance, show no special design"; and again, "A few large implements have been found equalling in workmanship and finish some " of the best of the valley specimens" (!). He says twice that the work on some of the "plateau " implements "is so slight as to be scarcely apparent." To add to the reader's uncertainty on the question of "plateau" implements the great geologist has given twelve incorrect references to his forty-one figures. It is known that Professor Prestwich at the time of writing his later papers was ill, overworked, and worried.

The conclusion I have come to is, that there are no such things as "eoliths" at all, nine out of ten of the thousands sent on to me for an opinion have been nothing but natural flint fragments, the tenth has been a minor and well-known palæolithic or neolithic form, or may be a bulbed, iron-stained, Victorian flake, knocked off by the hoof of a farm animal.

"Eoliths" on the Dunstable Plateau._" Eoliths" as such-to me-do not exist; all the different flint forms illustrated and described by Professor Prestwich and others, all the varieties seen in museums and private collections, occur near Dunstable in abundance; there is no line of demarcation between a palæolithic implement and an "eolith," as regards the weathering, abrasion, mineral condition and colour. The artificial gradually fades into the natural, the latter being in a large majority. Surely it is useless to argue whether a small doubtful piece rubbed out of the edge of a flint is artificial or natural, it is sheer waste of time. There is at Dunstable no archæological, geological, or osteological evidence that any of the worked stones on the plateau are so old as the boulder clay.

Only a few words need be said as to the genuine Dunstable high-level palæolithic implements, they entirely corroborate the statement made by Professor Prestwich, that implements occur from the rudest to the most highly finished. The four accompanying figures (Plate D., Figs. 1, 2, 3, and 4), drawn to half scale, show the varieties of implement; all are more or less abraded and discoloured. Figs. 1, 2, and 3 are of the abraded class. Fig. 3 is greatly abraded and deep brown in colour. I found it at Kensworth at a height of 760 feet and 210 feet above the nearest dry valley. There is no river near. Nothing older occurs in this neighbourhood nor, as far as I have

$$
\text { [ } 51 \text { ] }
$$



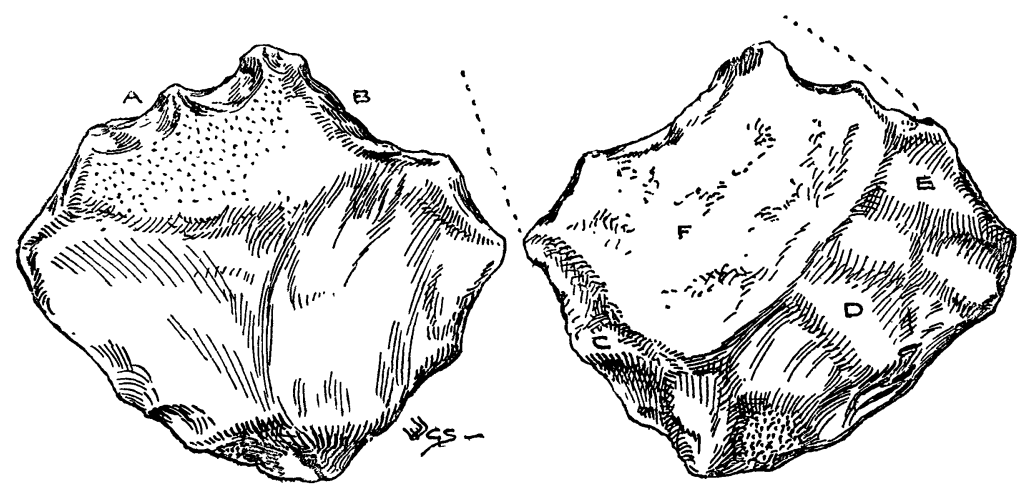

Fig. 7.-A Kentish " EOLITH," APPARENTLY MADE From THE BASAL PORTION OF A PALAOLITHIC IMPLEMENT. ( $\frac{1}{2}$ SCALE.) seen, anywhere else in England. Fig. 4 is an elaborately made and highly specialised form of the older class.

More may be said as to the "eoliths." The two stones illustrated in Figs. 5 and 6 would, without

doubt, be accepted as genuine "eoliths" by any believer in these dubious stones.

At Fig. 5, Plate D, is illustrated, in five views, to haif scale, a typical " eolith" from the Dunstable "plateau" ; it is a "pronounced" example with typically bruised, or vertically flaked edges. The surface of the stone, shown by dots, is abraded, ochreous, and of human origin ; the edges are newer, unabraded and creamy-livid in colour. If, therefore, the edges are " eolithic," it follows that the ochreous, human-made surfaces must be "pre-eolithic" as they are undoubtedly older than the surfaces.

Fig. 6, Plate D, is another and similar example, the edges show it to be an unmistakable "eolith," but it is made from a large, greatly abraded, artificial flake which must be "protoeolithic," as the surfaces are older and abraded, whilst the edges are newer and unabraded.

Turning for a moment from the Dunstable to Professor Prestwich's Kentish plateau, Fig. 7 is an accepted Kentish

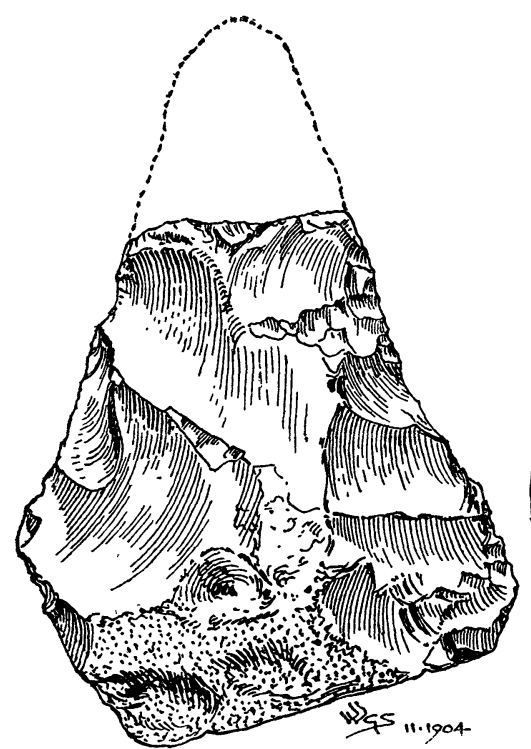

Fif. 9.-BASAL PORTION OF A KENTISH PALAOLITHIC IMPLEMENT SENT OUT AS A "PURE EOLITH" FROM A PURE "EOLITHIC" STRATUM. ( $\frac{1}{2}$ SCALE.)

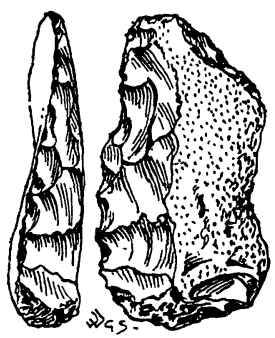

FIG. 8.-A PALAEOLITHIC BULBED AND TRIMMED FLAKE DOING DUTY AS AN "EOLITH" IN THE BLACKMORE MUSEUM, SALISBURY.

to me amongst

others for illus-

( $\frac{1}{2}$ SCALE.)

Benjamin Harrison, and labelled "Kent Plateau, 10 Aut. 2." The edges $\mathbf{A}$ and $\mathbf{B}$ are paler than the body of the stone, which is darker and older. On turning tbis accepted "eolith" over, it is seen to resemble the basal part of an ordinary abraded palæolithic implement. The palæolithic and abraded part at D, E, is scratched, whilst the "worked part" is unscratched. $\mathrm{F}$ is an old frost-break.

Of late still another aspect has been given to the subject of " eoliths"; the characters are always varying ; there is no finality or permanency in any of them. It is said that in certain favoured 
positions palæoliths have "never" been found in situ with the "eoliths." Now "never" is a long time. Take this example: There is a high-level position near Whipsnade Heatb, near Dunstable; everything is favourable at this place for a discovery of palæoliths. I have known the place well, and constantly visited it erer since I first began to notice implements, and have never met with an example there. This year a digger, known to me, was sent to dig stones for the road near Whipsnade Heath, and as soon as be began to dig he turned out a superb ochreous ovate implement, now No. 1,792 in my collection. Another example : Close by Dunstable is Blow's Downs, a place even more familiar to me than Whipsnade Heath. There are a few stains of brickearth on the fields of naked chalk, and I have never found anything like a palæolith on that part of the high ground. In October last a scholar from the Dunstable Grammar School in walking over the downs kicked his foot accidentally against a stone. On looking down he saw this stone to be a fine ovate palæolithic implement. He recognised the shape from having seen a small collection of implements given by me to the Grammar School here, and by others in my workroom. One should think twice before using the word "never."

To return to the pure "eolithic" strata. One of these positions is said to be at Alderbury, near Salisbury. I am deeply indebted to the kindness of Dr. H. P. Blackmore for obligingly sending me twenty-four examples from this position for illustration. One of these is given, to half scale, in Fig. 8. This specimen instead of being an "eolith," is on the face of it a good bulbed flake with very skilful, lateral palæolithic
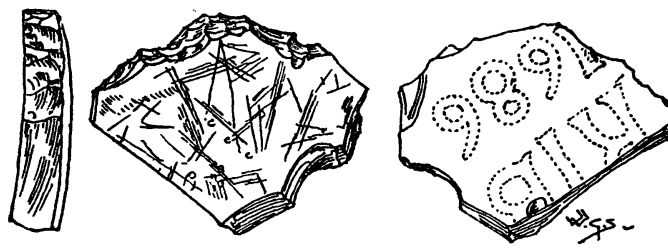

Fig. 10.-JACOBEAN SCRATCHED EXAMPLE OF "EOLITHIC" FORM IN BOTTLE GLASS, RAMRIDGE END, LUTON. ( $\frac{1}{2}$ SCALE.) flaking. There is in the Blackmore Museum, amongst "eoliths," a second and finer piece of work of this class five inches long from the same locality.

Another accepted "eolith" from a Kentish "pure stratum" is illustrated to half scale in Fig. 9. It was kindly forwarded to me, with others, for illustration by Mr. B. Harrison, from an "eolithic" position called, and the stone labelled, "Two Chimney House, E. 730 O.D.," a position from which no palæolithic traces had ever, it was said, been found. It will be seen that this pure "eolith" looks considerably like an ordinary palæolithic implement with the point knocked off.

In the earlier part of these notes I wrote of Victorian " eoliths." In Fig. 10 is illustrated a Jacobean "eolith." No one can look at the illustration without recognising the pure "eolithic" form and the genuine vertical "eolithic" chipping as seen on the edge view. The Jacobean "glacial" scratches on the surface should also be noticed. Prehistoric objects are not generally dated, but this example bears the date in bold embossed characters, "1686." The material is glass ; it is part of a thick, old dated bottle, and the vertical flaking was done by the boots of agricultural labourers, by the hoofs of farm animals, and by contact with farm implements. I found it in a high-level palæolithic position at Ramridge End, Luton.

Conclusion.-(1) The majority - nine out of ten of "eoliths"-are natural stones not intentionally touched by man.

(2) The minority are of human origin, but of well-known palæolithic or neolithic forms; these palæolithic minor forms being always found in company with palæolithic implements.

(3) There is no evidence that any of the minor palæolithic forms, often termed "eoliths," are so old as the boulder clay. WORTHINGTON G. SMITH. 